\title{
Mediating towards digital inclusion: the monitors of internet access places
}

\author{
Luísa Aires*, Rita Santos**, Javier Romero Díaz de la Guardia***, Catarina Lima****, Joana Correia***** \\ * Universidade Aberta, LE@D, Portugal \\ $* *$ Universidade de Aveiro, Digimedia (CIC. Digital), Portugal \\ *** Universidad de Granada, Spain \\ **** Universidade Aberta, CLA Ponte de Lima, Portugal \\ ***** Universidade Aberta, CLA Grândola, Portugal
}

Abstract

\begin{abstract}
Local dynamics play a key role in individual and collective empowerment for digital literacy and citizenship. This paper presents the results and reflections from a broader investigation into the public Internet access places in Portugal in the inland municipalities of the country's coast, undertaken by ObLID Network. Specifically, we intend to reflect on the actual mission of these places and reveal the actual profile, activities and training needs of their monitors and coordinators. In the first stage of the empirical study, several documents available on the Internet Spaces Network are analyzed. In the second stage, a questionnaire was applied to monitors and coordinators of the Internet access places, in seventeen Portuguese municipalities. The research results warn of the need to redefine and clarify the social and educational value of Internet spaces, indicating that the dominant activities of monitors in the Internet access places do not induce the foster of literacy and digital inclusion of the most vulnerable groups. In this context, actions are proposed that can contribute to improving the mission of Internet places, as well as the training quality of their monitors and coordinators. Internet Access Spaces, made available by municipalities, should be used to promote digital literacy programs, for individuals and groups.
\end{abstract}

Keywords: Digital inclusion and Citizenship; Digital literacy; Internet access places; Monitors; Coordinators; Training.

\section{Introduction}

In recent years, the ecology of access for digital technologies has changed significantly. According to the OberCom report (Cardoso, 2018) based on data from the INE (2016) and the Reuters Digital News Report (2017), in 2016, $67.4 \%$ of individuals in the sample report having used the Internet. This change also offers us a new scenario regarding the gender dimension, observing that the difference in the percentage of access between men and women has been reduced: $69.4 \%$ and $65.0 \%$ respectively. As far as the "age" dimension is concerned, the "traditional" reality remains, that is, the younger ones continue to be more active users than the older ones, although the gap in this dimension tends to decrease. Also according to this report, if we compare the reality of Internet access in 2016 and 2002 (19.4\%), the increase in access and use is close to 50 percentage points.

If we focus our analysis on a stricter approach to social participation and multiliteracy, the research on digital inclusion shows that there are also strong asymmetries in digital competences and, consequently, presents the urgent need to adopt inclusive measures in this field (Helsper, 2016; Selwyn \& Facer, 2013; Santos, 2014). In recent years, there have also been a number of European and national directives and initiatives that have tried to contribute to reducing differences in the use of digital media. This is the case of the "European Digital Competence Framework for Citizens", also known as DigComp, or the National Strategy for Digital Inclusion and Literacy (FCT, 2015). Among several actions, this Strategy created an intervention network, the ICT and Society Network, for digital inclusion and literacy, which involved several partners. There is also a further set of initiatives in the field, for example, in schools, municipalities, parish councils and libraries, which, although smaller in size and visibility, are focused on solving specific local problems. 
The research presented here is a result of one of those initiatives, the ObLID Network (Network of Research and Intervention on Literacy and Digital Inclusion)i, whose partners are several municipalities located outside the urban areas of the country's coastline. Directed at the analysis of the technological and educational reality, as well as the promotion of digital literacy and inclusion skills at the municipal level, ObLID Network has been highlighting the need to reinforce the intervention in this area, particularly with digitally excluded groups, in those less "central" areas (Aires, Santos \& Lima, 2015; Aires, 2014).

The Internet Spaces Network (UMIC, 2011) was one of the national initiatives, which created strong initial expectations for the promotion of digital inclusion. These places are understood as public places that have people, projects and equipment that facilitate access to the Internet, namely in municipalities in the interior of the country (Silva, 2012). Internet Spaces were considered potential context promoters of digital inclusion and development in local communities, and their coordinators and monitors would be dynamic agents of these processes. However, the network does not appear to be accompanying neither the changes in the digital ecology of the country nor the challenges that have arisen in relation to increasing the digital participation and citizenship of the more vulnerable public and in more remote areas.

Based on these assumption, the research questions of this research were:

- What is the current mission of Internet Access Spaces in less "central" areas?

- What is the profile, the main activities and the training needs of monitors and coordinators of the active Internet access places that integrate the ObLID Network?

To contribute to answering these questions, a survey was carried out with monitors and coordinators of active Internet access places in municipalities located away from the urban areas of the country's coast. The results obtained are hoped to contribute to identifying ways of reactivating these nuclei to promote digital inclusion, as through the training of the professionals who intervene in them.

\section{The Digital, a bridge to Inclusion}

In the approach to the phenomenon of digital inclusion, there are three identified tendencies that have influenced the intervention perspectives. The first perspective emphasizes a technological determinism in the practices of digital inclusion; the second perspective privileges the literacy dimension in the intervention in this field; the third one frames this problem in the context (Aires, Dias, Azevedo, Rebollo \& García-Perez, 2014). These tendencies are relevant when analysing possible strategies of intervention.

If, in educational research, a technological determinism has largely dominated with a tendency to reduce the concept to its instrumental dimension and to access digital tools, there are authors, such as Hertzer Hargittai (2008), who point out the existence of a second digital divide associated with asymmetries in skills and digital participation. Although the latter perspective is not dominant in educational and training contexts, it is known that more than concentrating efforts on whether or not to have access to technology, it is important to value the cultural practices through which access to technology is promoted, as well as the development and use of artefacts, contents and meanings (Hargittai, 2008; van Dijk, 2012; Warschauer, 2002). The analysis of communication practices in different social and cultural contexts is associated with hybrid textual practices, mediated by web pages, SMS, e-books, online fiction, wikis, social networks, among others (Vygotsky 1995, Cole, 1998). Linking digital inclusion to the development of digital knowledge, 
attitudes and skills that allow individuals to participate in collective life is an essential strategy to benefit a digital citizenship (Mossberger, Tolbert \& McNeal, 2008; Neves, 2010). Currently, van Deursen \& Helsper (2015) emphasize that the research has moved to a third-level digital divide, as the focus is no longer the skills and usages but the "tangible outcomes" of Internet use (2015:29). This holistic approach "allows better understanding of what aids or hinders an individual's ability to benefit from engaging with ICT and enables better design and evaluation of policy" (Helpser, 175:2016).

The emergence of digital citizenship with its consequent increasing of citizens' rights and responsibilities though/with online settings requires a new agenda for digital inclusion. Multiple perspectives on digital divide means a shift to a more complex intervention strategy that comprises individual, social, cultural, educational, economic and political contexts (Kim \& Choi, 2018). On the other hand, Fernández de Álava, Quesada \& García (2017) state that over the years, the digital divide should tend to shrink, but regardless of this, educational institutions should promote and plan the creation of curricula to overcome currently existing differences among digital natives, digital immigrants and digital pre-immigrants.

\section{The Local and the Digital}

Rural communities, being participants in the processes of globalization, are confronted with the need to associate traditional forms of production with new economies based on the production and commercialization of goods and services mediated by digital cultures (Vela \& Carcasona, 2015). Participatory processes, as a way of developing these communities, have been considered fundamental elements for opening up to these dynamics of change, positively translating into human development, empowerment of local communities and the reduction of social and digital ditches (Ahmad \& Abu Talib, 2015).

Being an ambiguous concept, local development is often perceived as a particular form of regional development, in which endogenous factors play an essential role (Coffey \& Polèse, 2005). Some of the chain of thought that include Mohan \& Stokke (2000), among others, advocate a more localized, inductive and less holistic view of development, focusing its operationalization on strategies such as decentralization of services, participatory development and training, development of cultural capital and collective actions. Community participation and empowerment are thus pillars in promoting quality of life, poverty reduction and local development (Ahmad \& Abu Talib, 2015; Wahid et al., 2015).

Bennet (2002) considers capacity building as a key pathway for the development of local communities, which in turn influences participation in decision-making processes, local resource management and, consequently, poverty reduction.

The development of digital competences is one of the vertices of this empowerment process. Despite the rapid expansion of access to and use of the mobile phone (Cardoso, Mendonça, Paisana, Lima \& Neves, 2015), Portugal still suffers from strong asymmetries and contradictions. The asymmetries in the country between the coast and the countryside (Silva, 2012), and particularly between the agricultural and urban communities, are reflected, among others, in the infrastructures and in the digital competences of the citizens, making these more vulnerable communities (FCT, 2013).

The improvement of digital skills in citizenship can contribute effectively to a better personal and social development of the individual and is a determinant to achieve equality and social inclusion. Literacy in the responsible use of technology as well as access and interaction in digital services are key factors for a proper 
development of people in the digital society and compliance with the current requirements of the labour market (Lázaro, Estebanell, \& Tedesco, 2015).

\section{Network of Internet Spaces: brief notes on its evolution}

Following the definition proposed by UMIC (2011), Internet Spaces are considered "(...) places of free public access, where computers and the Internet are regularly available, with support from their own staff (monitors) to facilitate the use of these technologies by people "(UMIC, 2011). The origin of the Internet Spaces Network dates back to the end of the 1990s, with the Digital Cities (1998-1999) and the Telecentres created under this project. In 2002-2003, new Internet Spaces were opened, under POSI (Operational Program for the Information Society). In this process of expansion, the Connect Portugal program, launched in 2006, played a decisive role.

According to the information available on the UMIC website (2011), in 2006, the network had 1.172 places effectively operating throughout the country. In 2008, according to this website, the Internet Spaces Network included 1.131 Internet Spaces.

Focused on social development, through the promotion of digital skills and free open access, the network of Internet Spaces covered a large number of institutions on a national level, involving Municipalities, Town Councils, Municipal Libraries, Associations, Social Solidarity Institutions, Centres for Social Inclusion and Internet Spaces (UMIC, 2011). Many of these institutions played "a very important role in the field of digital inclusion of citizens or social inclusion through digital technologies, offering them specific training in the area of ICT, supported by teams of monitors, trainers and facilitators" (Network Internet Spaces, 2012). In the spectrum of the Internet Spaces Network, monitors play the role of facilitators enabling the use of digital technologies by users of Internet Spaces, and these include citizens with special needs. As Internet Spaces integrate municipal structures and services, the monitors are part of the group that collaborates with municipalities and they are sometimes supervised by the Internet Spaces Coordinators, whose mission is to participate in the planning and execution of the projects in these places.

Despite the reasonable number of places, particularly in urban municipalities, data on who attended these places and for what purposes, for example, seem to have had little public visibility. As Ponte says in 2011, "(...) little is known about these spaces", and there are also indications that the approach followed in the dynamization of the Internet Spaces network was marked by a technological determinism that may have contributed to decrease their social and digital value (Ponte, 2011).

From exploring the website of the Network of Internet Spaces and the area related to the Network of Internet Spaces on the website of $\underline{\text { UMIC, }}$, we conclude that the content has not been updated since 2013 and 2011, respectively. The extinction of UMIC in 2012 and the divestment of FCT in the maintenance of this network seem to have been decisive milestones for the slowdown of network expansion.

This reality can be especially problematic in the rural areas and in the countryside. Despite the existence of global statistics that indicate a more optimistic reality (Europe's Digital Progress Report, EDPR, 2016), Municipalities are confronted with serious economic problems that also compromise the mission of Network of Internet Spaces. Rural areas are more affected by the lack of infrastructures and economic strength. 


\section{Study of the profile of Internet access places' monitors and coordinators}

To achieve the goals of better understanding the current mission of Internet Access Spaces in less "central" areas and the profile and the training needs of monitors and coordinators of the active Internet access places that integrate the ObLID Network, we used documentary analysis and survey questionnaire techniques. The methodology adopted was predominantly quantitative.

\section{Documentary analysis}

We analysed the documents available on the web, namely those in the Internet Spaces Network portalii, and created a sample that integrated the Internet access places, from 17 Portuguese municipalities ${ }^{\mathrm{iii}}$ (see second column of Table 1). To confirm this information and to obtain some general information about equipment, schedules and users of these spaces, the municipalities involved were contacted through the Local Learning Centres of the Open Universityiv (see third column of Table 1).

Table 1: Presentation of the information obtained regarding the Internet spaces of the municipalities involved in the research

\begin{tabular}{|c|c|c|}
\hline $\begin{array}{l}\text { Municipalities } \\
\text { associated with the } \\
\text { research }\end{array}$ & $\begin{array}{l}\text { Number of places referred to in } \\
\text { the Internet Spaces Network } \\
\text { Portal }\end{array}$ & $\begin{array}{l}\text { Number of Internet access } \\
\text { places } \\
\text { (direct contact) }\end{array}$ \\
\hline Abrantes & 1 & 4 \\
\hline Amarante & 4 & - \\
\hline Cantanhede & 2 & 2 \\
\hline Coruche & 2 & 2 \\
\hline Grândola & 2 & 1 \\
\hline Madalena & 1 & 2 \\
\hline Mêda & 2 & 1 \\
\hline Montijo & 7 & 8 \\
\hline Ponte de Lima & 3 & 3 \\
\hline Porto de Mós & 3 & 4 \\
\hline Praia da Vitória & 1 & 10 \\
\hline $\begin{array}{c}\text { Reguengos de } \\
\text { Monsaraz }\end{array}$ & 8 & 8 \\
\hline Resende & 2 & - \\
\hline Ribeira Grande & 9 & 12 \\
\hline Sabugal & 4 & 4 \\
\hline S. João da Madeira & 1 & 2 \\
\hline Silves & 1 & 2 \\
\hline
\end{tabular}

The generic exploration of this first data and information reveals the following reality (Aires, Santos \& Lima, 2015): 
There is a significant difference between the number of places mentioned on the website of the Network of Internet Spaces and the one mentioned by the municipalities. Some of the places of the Network of Internet Spaces are still working under the management of the municipalities. Other places have closed or have been used for other purposes. There are also situations in which municipalities refer to places that do not appear on the Internet site.

. The working hours of the active places are very variable. Some of these places offer schedules that do not facilitate their use by the active population;

- There are places that close at lunchtime due to the lack of human and financial resources of the municipalities;

. The technological equipment of these places is reduced;

In some cases, it is not possible to characterize the size and diversity of the support they provide because there are places where the number of users is not registered;

Young people, who show the lowest risk of digital exclusion, are the most frequent users of these places.

After identifying the Internet access places (IAP) that were active in the municipalities, the second phase went on with the application of a questionnaire to better understand the profile and activities of the monitors and coordinators of these places.

\section{Questionnaires}

We developed two questionnaires, one for the coordinators and another for the IAP monitors, with some questions in common. The main sections of the Monitors questionnaire were: a) Characteristics of the Internet access place and dominant activities; b) Functions in the Internet access place; c) Use of the Internet and Social Networks; d) Skills for the Digital Age; e) Socio-demographic characterization. The Coordinators' questionnaire had only sections (a), (b) and (e).

The questionnaire was made available online and contained mostly closed-ended questions. The contact with the IAP monitors and coordinators of the previously identified municipalities was mediated by the councillors of these municipalities. They were sent an e-mail to present the objectives of the questionnaire and to request its disclosure.

\section{Presentation and discussion of results}

A theoretical and purposive sample was created for this study. Overall, 52 individuals answered the questionnaires: 31 Monitors and 21 IAP Coordinators from 14 Municipalities. Table 2 summarizes the characteristics of the respondents who integrated this research. 
Table 2: Synthesis of the characteristics of the monitors and coordinators that integrated the present research

\begin{tabular}{|c|c|c|}
\hline & Monitors & Coordinators \\
\hline & $\mathbf{n}$ & $\mathbf{n}$ \\
\hline \multicolumn{3}{|l|}{ Sex } \\
\hline Male & 13 & 9 \\
\hline Female & 18 & 12 \\
\hline \multicolumn{3}{|l|}{ Age groups } \\
\hline $16-24$ & 3 & 0 \\
\hline $25-34$ & 7 & 2 \\
\hline $35-44$ & 10 & 10 \\
\hline $45-54$ & 9 & 6 \\
\hline $55-64$ & 2 & 3 \\
\hline \multicolumn{3}{|l|}{ Schooling level } \\
\hline Basic Education & 0 & 0 \\
\hline Secondary Education & 21 & 8 \\
\hline Bachelor's Degree & 9 & 11 \\
\hline Master's & 1 & 2 \\
\hline $\mathrm{PhD}$ & 0 & 0 \\
\hline $\mathrm{N}$ & 31 & 21 \\
\hline
\end{tabular}

The data shows that women dominate in the groups of monitors and coordinators, although the discrepancy is not very high. Most monitors are between 35 and 54 years old, while the coordinators lead in the age group of 35 to 44 . The group of monitors is led by individuals with qualifications at the secondary education level and coordinators are mostly university graduates, although 8 of these coordinators have secondary education qualifications.

\section{Monitors}

Regarding the IAP experience, monitors are predominantly divided into two subgroups: $38.57 \%$ (12) have worked between 3 and 6 years and a relatively similar percentage (37.5\%) has worked for less than 3 years, as shown in the following graph (Figure 1$)$. The clear majority $(77.4 \%, n=24$ ) of monitors perform fulltime functions in these places (Figure 2). 
Figure 1: How long have you been working in IAP

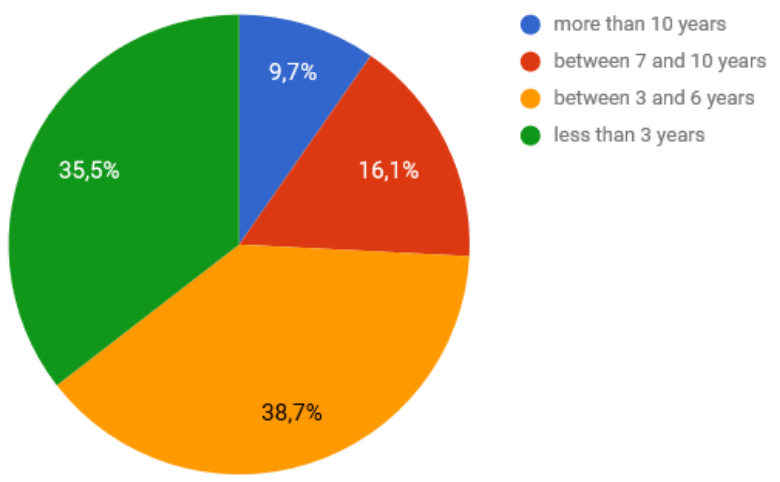

The instability in the constitution of the teams of monitors is a factor that can put in question the sustainability of the network. The high turnover of human resources weakens the focus on the specific training of this group of professionals, with devastating consequences on the consistency and coherence of the EAI mission. Data obtained in the informal analysis show that, in recent times, the recruitment of monitors from the employment centers, from the pool of the unemployed, is recurrent, with their position in these spaces limited to a few months.

The vast majority $(77.4 \%, \mathrm{n}=24$ ) of monitors perform full-time functions in these places (Figure 2).

Figure 2: Time spent at IAP

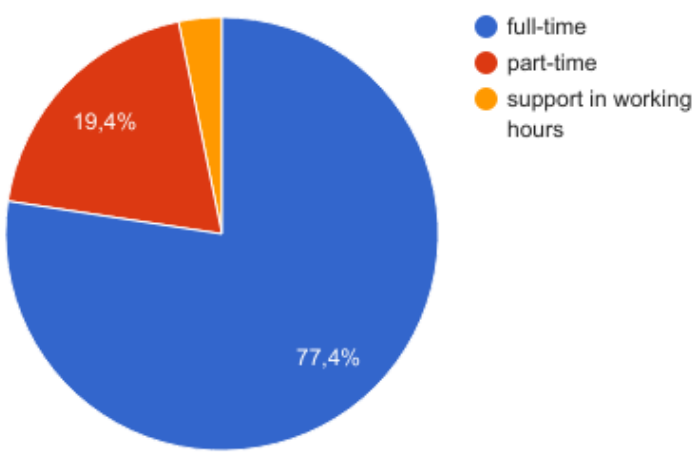

An open response was used to find out about the monitors' daily routines in IAP; the majority referred to support for users in tasks such as printing or Internet use, turning on/off computers and controlling the time available for each user (Figure 3). However, two responses show that the IAP monitors can have other functions, in addition to the previously mentioned routines: one monitor referred to also serving in the bar and helping children and young people with the school work and another indicated being involved in animation projects and entertaining pedagogical activities (2 cases), showing no evidence of these being related in any way to the use of ICT and the development of digital competences.

These data corroborate the current lack of clarity of the IAP network, as well as, in some IAPs studied, the non-differentiation of the functions that their monitors perform. They also indicate that in some cases, there is either no evidence of the technological determinism present in other IAPs, as pointed out earlier by Ponte (2011). 
Figure 3: Daily routines in IAP

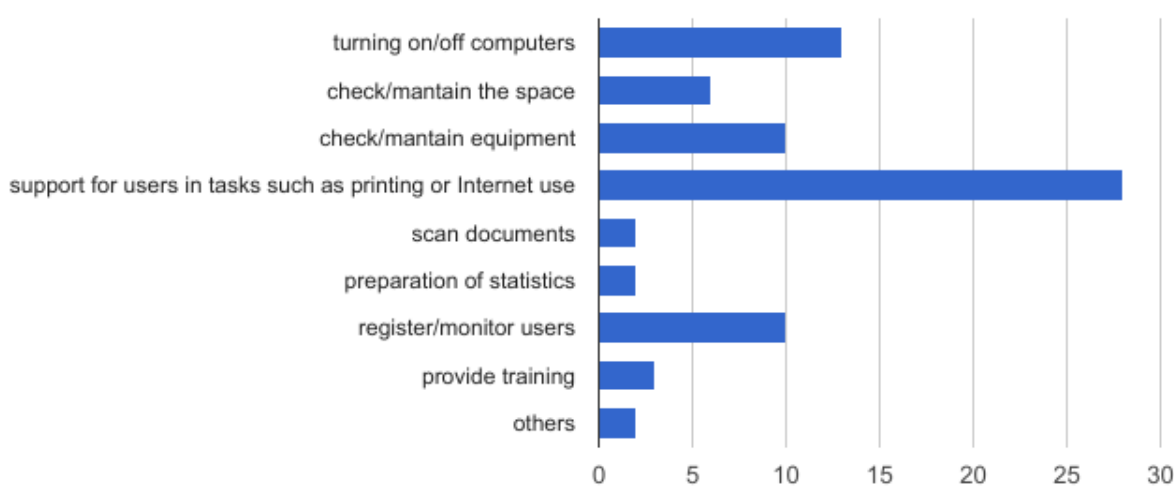

When questioned about their involvement in planning the activities developed in IAPs, the reality that emerges in this dimension is diverse. If the majority of the monitors are integrated into the planning of activities, through collaborative dynamics, 32.3\% $(n=10)$ are not involved in these dynamics, being a passive part of a top-down planning logic, and still others $(16.1 \%, n=5)$ perform this task alone (Figure 4).

Figure 4: Planning the activities of the IAP

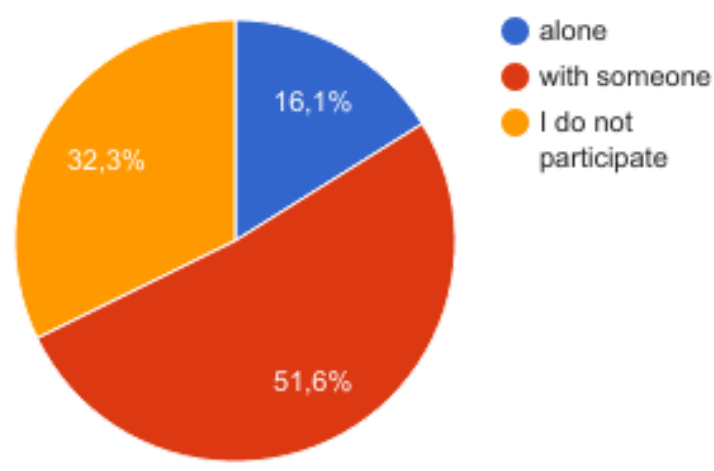

Regarding the specific training to perform monitor functions, $90.3 \%(n=28)$ indicated that they did not receive any training (Figure 5 ).

Among those who received training $(n=3)$, search and selection of information on the Internet, installation and maintenance of hardware and software installation and maintenance are referred to as the dominant areas of training (Figure 5). 
Figure 5: Training to perform functions in the IAP and type of training

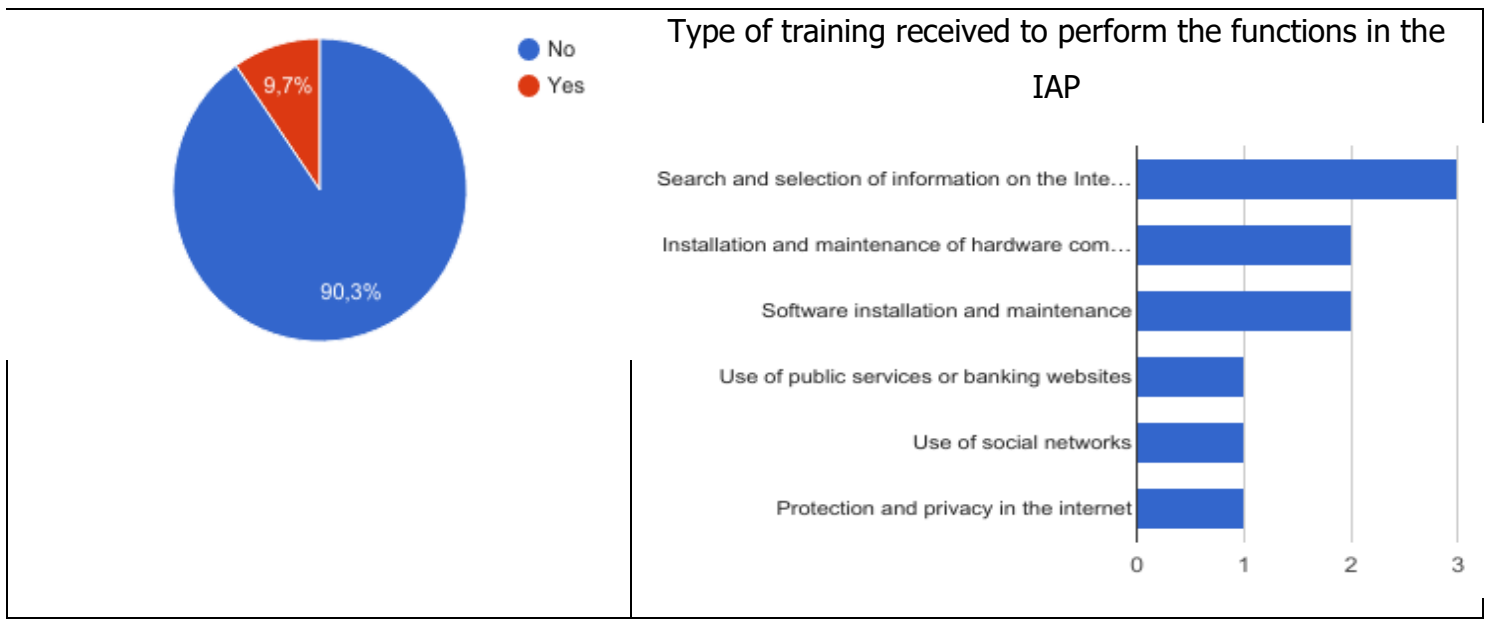

As for future training, monitors who are interested in attending training refer the following preferences (Figure 6): Internet protection and privacy, software installation and use, use of portals and public services, hardware maintenance and information technologies skills (e.g. programming languages).

As to their training needs, there is a perceived lack of necessity for further training in addition to knowledge of instrumental technology conceptions in approximately $42 \%$ of the monitors (Figure 6 ), suggesting a reduced future perspective regarding the functions they perform. These data confirm, once again, on the one hand, the presence of a technological determinism that marked the design of this network, as pointed out by Ponte (2011), and on the other, a blurred picture of the mission of the IAP network.

Figure 6: Interest in receiving training in the ICT area and preferred areas of training

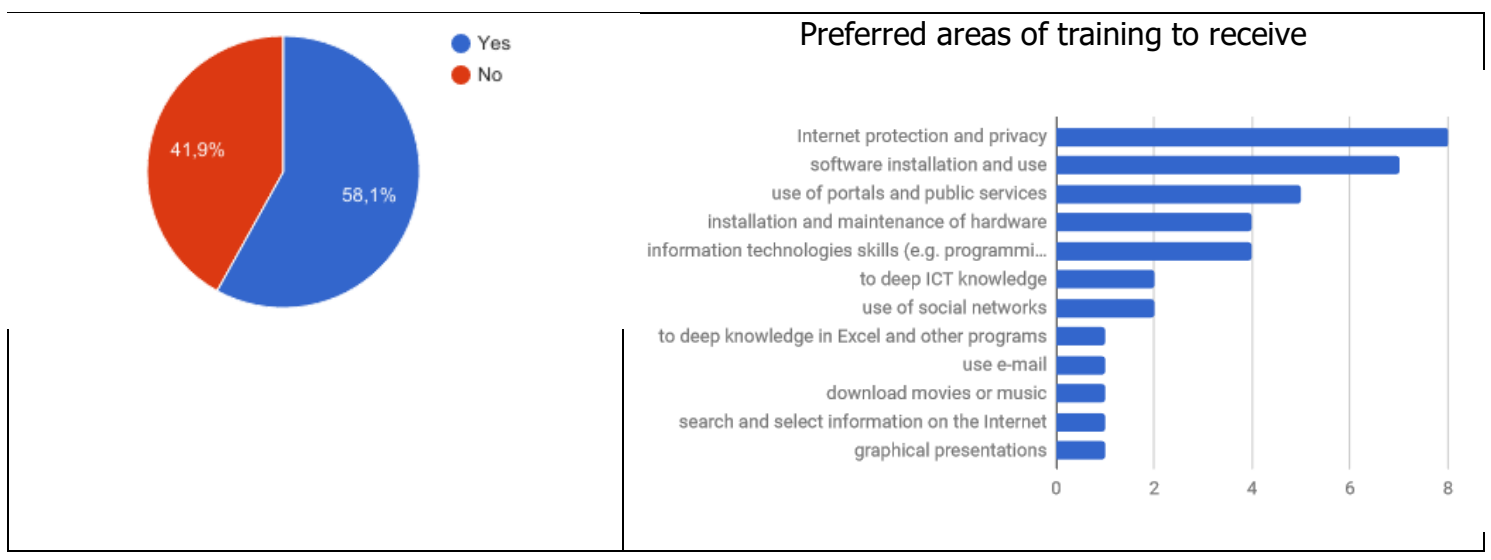

\section{Coordinators}

Coordinators have been performing this role for different period: $23.8 \%(n=5)$ have been coordinators for more than 10 years; $38.1 \%(n=8)$ have performed the functions for 7 to 10 years; $28.6 \%(n=6)$ have been IAP coordinators for less than 3 years (Figure 7). 
Figure 7: How long have you been coordinating

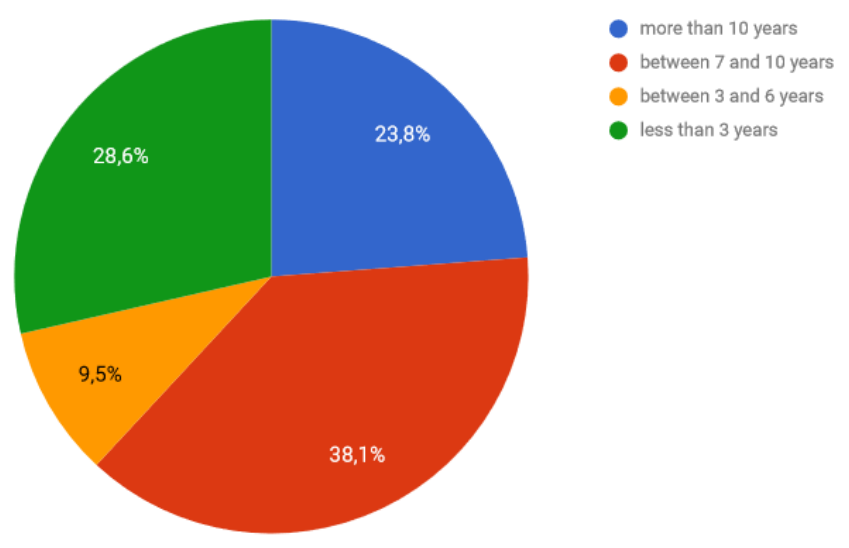

As far as the daily routines of the coordinators are concerned (Figure 8), most refer to supporting users. Training routines are followed by user control. In some cases, they mentioned place management/coordination without discriminating specific tasks. Finally, it should be pointed out that 7 coordinators did not mention any type of activity in their responses.

Figure 8: Daily coordinator routines in IAP

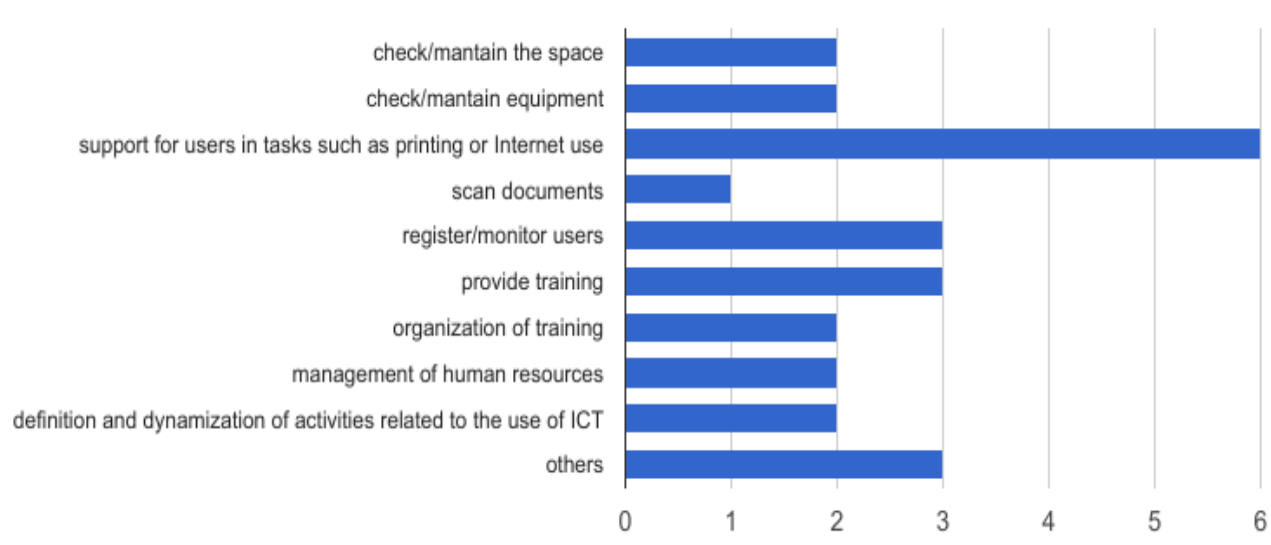

It was also verified that the planning of the activities of the coordinators is done together with the team that works in the IAP in $52.6 \%(n=10)$ of the cases, in $21.1 \%(n=4)$ of the individual cases and that $15.8 \%$ $(n=3)$ reported not participating in planning (Figure 9 ). 
Figure 9: Planning activities in the IAP

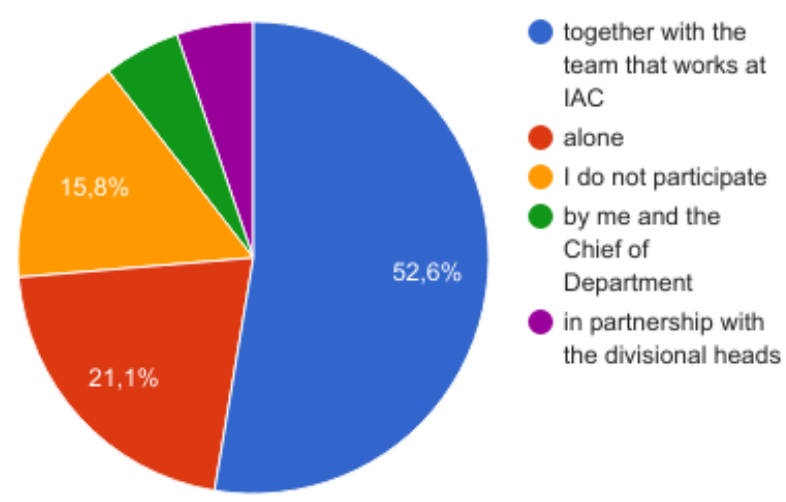

If, in the case of the coordinators, there is a greater percentage of permanence in the functions, as well as a higher level of education, the absence of training to perform their functions is also verified, the same as with the monitors, since $76.2 \%(n=16)$ did not receive specific training to be IAP coordinator (Figure 10).

Figure 10: Training to perform coordination functions in the IAP

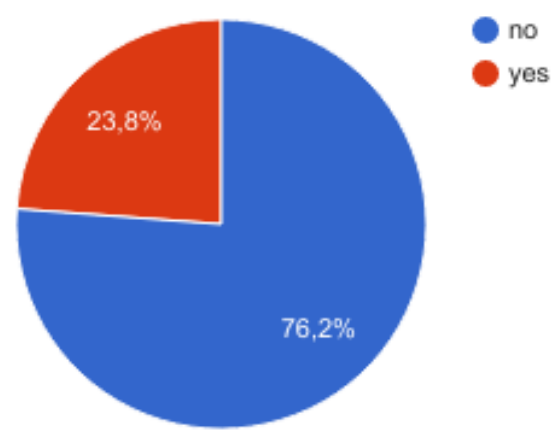

As for the training that $23.6 \%(n=5)$ say they have received, the main training areas are: search and selection of information on the Internet, use of public service or banking portals, use of social networks and protection and privacy on the Internet (Figure 11). In this dimension, a less instrumental approach to technologies and the development of competencies that are more oriented towards multiple literacies, essential for the exercise of participation and digital citizenship, is observed by comparison with the monitors. 
Figure 11: Type of training received for coordination functions in the IAP

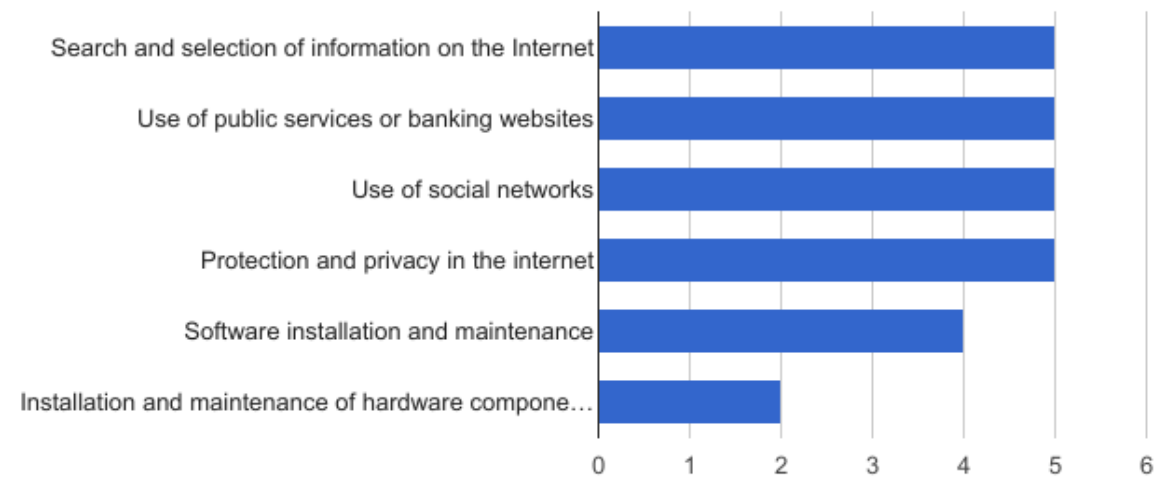

To sum up with, the data collected with the application of the questionnaires allow us to build the following monitor and IAP coordinator profiles:

\section{Monitors}

The dominant academic background of the group of informants is secondary education and $77.4 \%$ work full-time in these areas.

As for the daily routines followed by the monitors, the majority mentioned opening the places, verifying the equipment, helping users, controlling the time available for each user, scanning document scans and doing statistics.

$50 \%$ of the monitors plan activities with someone. However, $32.3 \%$ do not participate in planning and $16.1 \%$ plan IAP activities alone.

A large majority did not attend specific training for the functions performed and, of the $9.7 \%$ who did receive training, the dominant areas are: research and selection of information on the Internet, installation and maintenance of hardware and installation and maintenance of software.

When $58.1 \%$ expressed an interest in receiving training in the ICT area, $41.9 \%$ stated that they had no interest in acquiring specific training.

The most prized training areas are: Hardware Installation and Maintenance; Installation and use of software; Protection and privacy on the Internet; Use of public service or banking portals, programming languages, use of new software, Data Security; Graphic Presentations.

\section{Coordinators}

In the group of the Coordinators, the average level of schooling is higher: university graduates dominate, although 8 coordinators refer having only completed secondary education. The duration of their experience in these functions is also variable: $23.8 \%$ have worked for more than 10 years; $38.1 \%$ have performed the functions for 7 to 10 years; and $28.6 \%$ for less than 3 years. As daily routines, the majority refers to supporting users, followed by user control and training. $52.6 \%$ indicate that the planning of IAP activities is done together with the IAP team. However, $21.1 \%$ plan on their own and $15.8 \%$ do not participate in planning. Like monitors, $76.2 \%$ did not receive specific training for the IAP coordination functions. 


\section{Prospective actions}

The results of this research have evidenced a lack of training in certain areas that can significantly affect the professional performance of the IAP monitors and coordinators, as it has been detected that most of them did not attend specific training regarding their attributions in the work place.

It is believed that a training activity should be designed and implemented based on a common content structure but providing the trainees with different training paths for the coordination and monitoring roles, to offer contextualized sets of activities in each case. The following paragraphs give an overview of the general guidelines that will be followed in the implementation of the training activity.

The training program will be built under a framework of universality, openness and accessibility and deployed in e-learning modality using a virtual learning environment based in Moodle as a central scenario, although the use of external tools, as social networks, will be needed as well.

Educational materials in this course will be developed as Open Educational Resources that will be published in the "Repositório Aberto (UAb)", an institutional repository provided by Universidade Aberta of Portugal with the objective of storing, preserving and publicizing the intellectual production in digital formats.

As per the contents, there are four main areas to be covered:

- Effective integration of ICT in the professional practice in an IAP

Public service and daily activity in an IAP

Collaborative problem solving and case studies

Planning and IAP enhancement.

The design of the training activity will feature the approach of collaborative activities, including the possibility of setting up peer tutoring scenarios. The idea is to lay the foundations for a future collaboration between coordinators and monitors of different IAPs, generate group feeling and encourage dynamics of dissemination of experiences and good practices from some IAPs that can be harnessed and replicated in others. Likewise, the use of personal learning environments (PLE) integrated with the e-learning platform will be facilitated and stimulated so that they provide a place to reflect learning experiences and establish professional links with colleagues from other workplaces.

To increase motivation and interest in their ongoing and permanent training, it is proposed the configuration and implementation of a recognition system based on the use of digital badges. These badges might be granted when the main milestones of the training activity are overcome, and they could be made public by appearing in the participants' social network profiles and their PLE.

It should be noted that this approach to the training of the monitors can only be thought of in the framework of the redefinition of the mission of the IAPs, from the perspective of seeing them as spaces of digital citizenship.

In this new mission, the instrumental dimension of technologies is replaced by the technology-mediated human development perspective of citizens. Coordinators and monitors are digital mediators who promote new forms of literacy, oriented toward the appropriation of norms and responsible behaviors in the use of digital technologies and environments (Simsek \& Simsek, 2013). Its action is oriented towards the empowerment of individuals within the framework of a digital citizenship, understood in the perspectives of Gleason \& von Gillern (2018) and Gazi (2016: 139) as "a socially constructed set of practices and the norms of behaviors where facilitates individual development and protects social values in digital society ". 


\section{Limitations of the study}

Because a quantitative methodology was used, it was not possible to explore other issues related to the meanings of the experiences in the Internet places. For that reason, there is an ongoing doctoral thesis that adopts a qualitative and comprehensive perspective on this issue.

\section{Conclusions}

Public Internet access places can play a key role in the access of excluded groups to the digital society, especially in remote areas away from the coast and in large urban centres.

The study here presented was guided by two research questions. Regarding the first question "What is the current mission of Internet Access Spaces in less "central" areas? ", the analysis presented in this article showed a growing weakening of the network that supported many of these places and, in some cases, the extinction of the project. Most IAPs today have a diffused mission that departs, on the one hand, from the mission for which they were created and, on the other hand, from the mission that they were supposed to have in the 21st century.

Concerning the second question, "What is the profile, the main activities and the training needs of monitors and coordinators of the active Internet access places that integrate the ObLID Network?", it was possible to conclude that both monitors and coordinators are mainly carrying out tasks related to support users in tasks such as printing or Internet use, activities that do not foster the literacy and digital inclusion of the most vulnerable groups. There are also few involved in planning or providing training activities, which is particularly worrisome in the cases of coordinators, to whom it would be natural to be assigned this type of function. Also cause for concern is the fact that some monitors and even few coordinators are not participating in the planning activities in the IAP.

The absence of specific training for monitors and coordinators, their schooling level and some lack of interest in training, associated with fragile technological infrastructures and operating dynamics are also indicators that merit reflection.

IAP monitors and coordinators should be mediators for skills development and digital inclusion. However, the training for these groups, when there is some, is instrumentalist and does not contemplate community intervention as a basis for action.

In view of the data obtained, and the reality of digital exclusion that particularly affects citizens who live in communities far from the major urban centres, it is necessary to rethink public places for Internet access, namely the training offered, proposing their reshaping as spaces for the development of digital participation and citizenship. 


\section{References}

Ahmad, M.S., \& Abu Talib, N.B. (2015). Empowering local communities: decentralization, empowerment and community driven development, Quality and Quantity, vol.49, issue 2, 827-838. DOI: $10.1007 / \mathrm{s} 11135-014-0025-8$

Aires, L., Santos, R., \& Lima, C. (2015). Espaços Internet e Inclusão Digital. In C. Ferreira, S. B Dias \& J. A. Diniz, (eds.), Proceedings of the 9th International Conference on Digital Exclusion in the Information and Knowledge Society (pp. 47-48). http://goo.gl/XBoc2

Aires, L. (2014). From Dissemination to the Domestication of Digital Technologies in Rural Communities: Narratives of Parents and Teachers, Mind, Culture, and Activity, 21:4, 337352, DOI: $10.1080 / 10749039.2014 .947654$

Aires, L., Dias, P., Azevedo, J., Rebollo, M.A., \& García-Perez, R. (2014). "Education, Digital Inclusion and Sustainable Online Communities", Ulisses M. Azeiteiro, Walter Leal Filho \& Sandra Caeiro (eds.) ELearning and Education for Sustainability, pp. 263-273. Peter Lang GmbH International Academic Publishers. ISSN 1434-3819 ISBN 978-3-631-62693-1 (Print) E-ISBN 978-3-653-02460-9 (E-Book) DOI: $10.3726 / 978-3-653-02460-9$.

Aires, L. (2014). "She has the computer, but what for? The changes of digital inclusion in rural communities". Porto, European Educational Research Association/ ECER, 1-5 setembro.

Azevedo, J., \& Seixas, M. (2011) Questões de género na participação digital. Media \& Jornalismo, 10(2), 5980. Retrieved from http://goo.gl/qAaxVa

Bennett, L. (2002). Using empowerment and social inclusion for pro-poor growth: a theory of social change. Working draft of a background paper for the Social Development Strategy Paper, World Bank, Washington, $D C$.

Cardoso, G. (coord.) (2018). Literacias na Sociedade dos Ecrãs. Relatórios OberCom. Lisboa, OberCom. Retrieved from: https://obercom.pt/wp-content/uploads/2018/03/OberCom2018-Literacias-naSociedade-dos-Ecra\%CC\%83s.pdf

Cardoso, G., Mendonça, S., Lima,T., Paisana, M., \& Neves, M. (2014). A Internet em Portugal - Sociedade em Rede 2014. Retrieved from: http://goo.gl/a88bM4

Coffey, W., \& Polèse, W. (2005). The concept of local development: a stages model of endogenous regional growth. Regional Studies, 19, 85-93

Cole, M. (1998). Cultural Psychology: A Once and Future Discipline. Harvard University Press.

European Commission (2016). Europe's Digital Progress Report 2016. Retrieved from: http://goo.gl/MJGLaA

FCT (2013). Vulnerable People \& ICT in Portugal: the practice of more than 15 years. Retrieved from: http://goo.gl/DqlHRW

FCT (2015). Estratégia Nacional para a Inclusão e Literacia Digitais (2015 - 2020). Retrieved from: http://www.fct.pt/dsi/inclusaoacessibilidadeliteraciadigitais/enild

Gleason, B., \& von Gillern, S. (2018). Digital Citizenship with Social Media: Participatory Practices of Teaching and Learning in Secondary Education. Educational Technology \& Society, 21 (1), 200-212.

Helsper, E. (2016). Inequalities in digital literacy: definitions, measurements, explanations and policy implications. In Comitê Gestor da Internet no Brasil (Ed.), Survey on the use of information and communication technologies in Brazilian households : ICT households 2015 (pp. 175-185). Retrieved from: $\underline{\mathrm{http}: / / \mathrm{goo} . \mathrm{gl} / 4 \mathrm{dbx} 76}$ 
Jenkins, H., Purushotma, R., Weigel, M., Clinton, K., \& Robison, A. J. (2009). Confronting the challenges of participatory culture: Media education for the 21st century. MIT Press.

Kim, M., \& Choi, D. (2018). Development of Youth Digital Citizenship Scale and Implication for Educational Setting. Educational Technology \& Society, 21 (1), 155-171. Retrieved from: http://www.jstor.org/stable/26273877

Lázaro, J. L., Estebanell, M., \& Tedesco, J. C. (2015). Inclusion and Social Cohesion in a Digital Society. International Journal of Educational Technology in Higher Education, 12(2), 44-58. DOI: 10.7238/rusc.v12i2.2459

Mohan, G. \& Stokke, G. (2000). Participatory development and empowerment: The dangers of localism. Third world quarterly, 247-268. DOI: 10.1080/01436590050004346

Mossberger, K., Tolbert, C., \& McNeal, R. (2008). Digital Citizenship. The Internet, Society, and Participation. Cambridge: MIT Press. Retrieved from: http://selembarpapyrus.com/wpcontent/uploads/2017/09/Digital-Citizenship-The-Internet-Society-and-Participation-KarenMossberger-Caroline-J.-Tolbert-Ramona-S.pdf

Neves, B. (2010). Cidadania Digital? Das cidades digitais a Barack Obama. Uma abordagem crítica. Cidadania Digital, 143-188 Junho. Retrieved from: http://bbneves.com/wpcontent/uploads/2010/02/Cidadania-Digital.pdf

Pew Research Center (2014). Digital Life in 2025. Retrieved from: http://goo.gl/CEhKLb

Ponte, C. (2011). A rede de Espaços Internet entre os paradoxos e desafios da paisagem digital. Revista Media \& Jornalismo (19), 39-58. Retrieved from: http://goo.gl/NsysEl

Rede Espaços Internet (2012). Rede Espaços Internet. Retrieved from: http://www.umic.pt/index.php?option=com content\&task=view\&id=18\&Itemid=

Rede ObLID. Rede de Investigação e Intervenção para a Literacia e a Inclusão Digital. Available: www.contemcom.otrg.

Romero Días, J. J. (2013). Técnicas y Estrategias Didácticas para la Autoría y Despliegue de Materiales Educativos Digitales en Entornos Virtuales de Formación: Análisis en el Marco del Plan de Formación del Profesorado Escuela TIC 2.0. Universidad de Granada: Doctoral Thesis.

Santos, R. (2014). Usos da Internet pelos alunos do Ensino Superior: Envolvimento, Literacia e Oportunidades (PhD's Thesis, University of Porto/ University of Aveiro). Retrieved from: http://goo.gl/t8Lk6Z

Selwyn, N., \& Facer, K. (2010). Beyond Digital Divide: Toward an Agenda for Change. In E. Ferro, Y. Dwivedi, J. Gil-Garcia, \& M. Williams (Eds.), Handbook of Research on Overcoming Digital Divides: Constructing an Equitable and Competitive Information Society (pp. 1-20). DOI:10.4018/978-160566-699-0.ch001

Silva, J.M.F. (2012). As assimetrias regionais em Portugal: análise da convergência versus divergência ao nível dos municípios (Master's thesis, University of Aveiro). Retrieved from: http://goo.gl/yypHZy

UMIC (2011). Rede de Espaços Internet. Retrieved from: http://goo.gl/fF4w8z

Wahid, A., Ahmad, M. S., Abu Talib, N. B., Shah, I. A., Tahir, M., Jan, F. A., \& Saleem, M. Q. (2015). Barriers to empowerment: Assessment of community-led local development organizations in Pakistan. Renewable and Sustainable Energy Reviews. DOI: 10.1016/j.rser.2016.11.163

Van Deursen \& A., Helsper, E. (2015). The Third-Level Digital Divide: Who Benefits Most from Being Online?, In Laura Robinson, Shelia R. Cotten, Jeremy Schulz, Timothy M. Hale \& Apryl Williams(ed.)Communication and Information Technologies Annual (Studies in Media and 
Communications, Volume 10). Emerald Group Publishing Limited, 29 - 52. DOI: $10.1108 /$ S2050-206020150000010002

Van Dijk, J.G.M. (2012). The Evolution of the Digital Divide - The Digital Divide turns to Inequality of Skills and Usage. In J. Bus et al. (Eds.), Digital Enlightenment Yearbook 2012 (pp.55-75). DOI: 10.3233/978-1-61499-057-4-57

Warschauer, M. (2002). Reconceptualizing the Digital Divide. First Monday, 77 ). DOI: http://dx.doi.org/10.5210/fm.v7i7.967

Vela, J., \& Barniol-Carcasona, M. (2015). The relationship between branding and local development. A case study in the Catalonia's countryside:Territoris Serens. Journal of Rural Studies, 37, 108-119. DOI: http://dx.doi.org/10.1016/j.jrurstud.2015.01.001

Vigotsky, L.S. (1995). Obras Escogidas (tomo III). Madrid: Visor.

\footnotetext{
i The network ObLID (https http://contemcom.org//) was created in 2010, resulting from a partnership between CETAC.Media (University of Porto/University of Aveiro), the Universidade Aberta (UAb) and the Municipalities of Resende and Amarante. Currently, ObLID Network is hosted at LE@D research centre, Universidade Aberta. Available at http://contemcom.org

ii Consulted on june, 2016.

iii The municipalities that collaborated in the study were the partner municipalities of the Oblid Network (partner municipalities of Open University and founding municipalities of Oblid Network):Abrantes, Amarante, Cantanhede, Coruche, Grândola, Madalena, Mêda, Montijo, Ponte de Lima, Porto de Mós, Praia da Vitória, Reguengos de Monsaraz, Resende, Ribeira Grande, Sabugal, S. João da Madeira \& Silves.

iv Contact in july, 2014.
} 